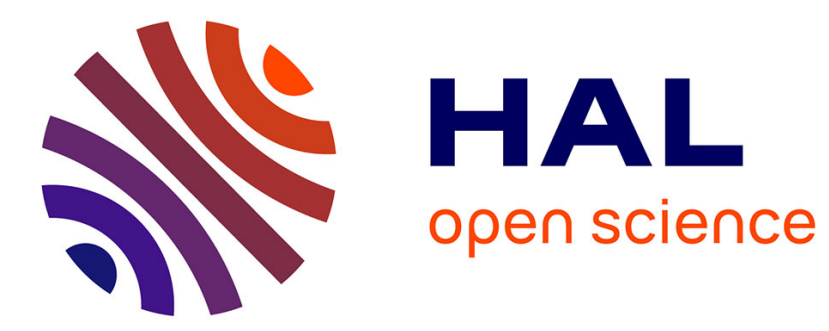

\title{
Microwave-assisted multi-step synthesis of novel pyrrolo-[3,2-c]quinoline derivatives
}

Hafid Benakki, Evelina Colacino, Christophe Andre, Farhate Guenoun, Jean Martinez, Frédéric Lamaty

\section{- To cite this version:}

Hafid Benakki, Evelina Colacino, Christophe Andre, Farhate Guenoun, Jean Martinez, et al.. Microwave-assisted multi-step synthesis of novel pyrrolo-[3,2-c]quinoline derivatives. Tetrahedron, 2008, 64, pp.5949-5955. 10.1016/j.tet.2008.04.034 . hal-00281037

\section{HAL Id: hal-00281037 https://hal.science/hal-00281037}

Submitted on 1 Feb 2021

HAL is a multi-disciplinary open access archive for the deposit and dissemination of scientific research documents, whether they are published or not. The documents may come from teaching and research institutions in France or abroad, or from public or private research centers.
L'archive ouverte pluridisciplinaire HAL, est destinée au dépôt et à la diffusion de documents scientifiques de niveau recherche, publiés ou non, émanant des établissements d'enseignement et de recherche français ou étrangers, des laboratoires publics ou privés. 


\title{
Microwave-assisted multi-step synthesis of novel pyrrolo-[3,2-c]quinoline derivatives
}

\author{
Hafid Benakki ${ }^{a}$ b ${ }^{\text {, Evelina Colacino }}{ }^{\mathrm{a}}$, Christophe André ${ }^{\mathrm{a}}$, Farhate Guenoun ${ }^{\mathrm{b}}$, \\ Jean Martinez ${ }^{a}$, Frédéric Lamaty ${ }^{\mathrm{a}, *}$ \\ a Institut des Biomolécules Max Mousseron, UMR 5247 CNRS-Université Montpellier 1 et Université Montpellier 2, Place Eugène Bataillon, 34095 Montpellier Cedex 05, France \\ ${ }^{\mathrm{b}}$ Université My Ismaïl, Faculté des Sciences, BP 11201, Zitoune, Meknès, Morocco
}

\begin{abstract}
A B S T R A C T
A new approach for the synthesis of original substituted pyrrolo-[3,2-c]quinoline derivatives using microwave-assisted chemistry is described. The use of microwave activation in this synthesis resulted in high yielding and clean steps. The key step for introducing diversity is the amination or the Pd-catalyzed cross-coupling of an imidoyl chloride derivative, obtained in a straightforward manner and in good yield.
\end{abstract}

Keywords:

Microwave activation

Suzuki coupling

Aza-Baylis-Hillman

Ring-closing metathesis

\section{Introduction}

Microwave-assisted chemistry ${ }^{2}$ has greatly expanded in recent years with the arrival of specifically adapted equipment for the synthesis. The microwave-assisted synthesis found its first applications in organic chemistry, where some reactions proved to be 100 times faster with the microwave heating than with traditional ones (oil bath, etc.). The involved reactions are very often cleaner. Many organic reactions have been explored and adapted under microwave activation. ${ }^{3,4}$ Examples of multi-step synthesis in which each step requiring heating performed under microwave are scarce in the literature. We report herein a new microwave-enhanced multi-step synthetic pathway for the preparation of pyrrolo-[3,2c]quinoline derivatives.

The pyrrolo-[3,2-c]quinoline and its analogue pyrroloquinoxaline skeleton (Fig. 1) have been known for several years as one of the most widely used motifs in medicinal chemistry. Several derivatives of such heterocycles possess a wide spectrum of biological activities, including most notably antitumor ${ }^{5}$ and hypotensive ${ }^{6}$ properties, gastric $\left(\mathrm{H}^{+} / \mathrm{K}^{+}\right)$-ATPase inhibition, ${ }^{7-9}$ anti-inflammatory activities, ${ }^{10}$ and $5-\mathrm{HT}_{3}$ agonism ${ }^{11-13}$ (Fig. 1). The discovery of bradykinine receptor agonist in an extract from the tropical plant Martinella iquitosensis ${ }^{14}$ has renewed the interest of

\footnotetext{
* Corresponding author.

E-mail address: frederic.lamaty@univ-montp2.fr (F. Lamaty).
}

researchers to plan new synthetic approaches $8,10,15,16$ for the preparation of these molecules.

The wide potential of such a structure core unit has prompted us to develop an alternative synthetic route for the synthesis of 4amino-1-methyl-4-1H-pyrrolo-[3,2-c]quinoline and 4-aryl-1-methyl-4-1H-pyrrolo-[3,2-c]quinoline derivatives.

As a continuation of our ongoing studies in the development of novel routes for the synthesis of substituted pyrroles, ${ }^{17,18}$ an alternative and convenient pathway leading to new series of pyrrolo$[3,2-c]$ quinoline derivatives is presented. The key intermediate is an imidoyl chloride and the diversity was introduced efficiently using microwave-activated amination ${ }^{11-13,19-22}$ and Suzuki ${ }^{2,19,22-27}$ cross-coupling reaction. In recent years these methods have found a widespread application in several areas of organic synthesis because they lead to the $\mathrm{C}_{\mathrm{sp}^{2}}-\mathrm{N}$ or $\mathrm{C}_{\mathrm{sp}^{2}}-\mathrm{C}_{\mathrm{sp}^{2}}$ bond formation, which cannot be easily formed using classical transformations.

The proposed retrosynthetic approach of imidoyl chloride $\mathbf{8}$ is presented in Scheme 1.

Examination of Scheme 1 reveals that, 4-chloro-1-methyl$1 H$-pyrrolo-[3,2-c]quinoline can be obtained from the corresponding amide via a chlorination reaction, and 1-methyl$1 H$-pyrrolo-[3,2-c]quinolin-4(5H)-one in turn would arise from cyclization of 1-methyl-2-(2-aminophenyl)-1H-pyrrole-3-carboxylate. The latter precursor would be synthesized according to the procedure, which has been developed in our group, ${ }^{18}$ via an aza-Baylis-Hillman/ring-closing metathesis/aromatization sequence. $^{28-30}$ 


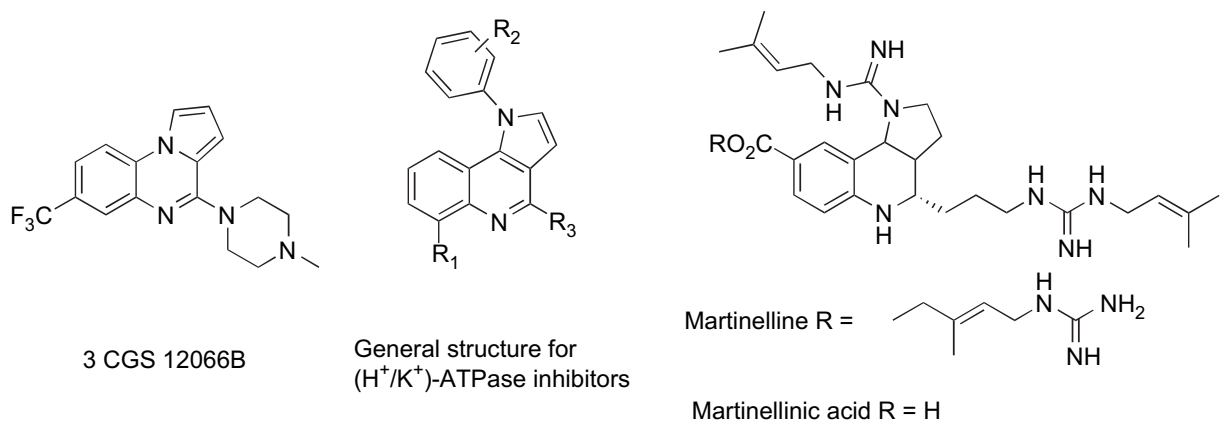

Figure 1. Examples of active pyrroloquinoline and quinoxaline derivatives.

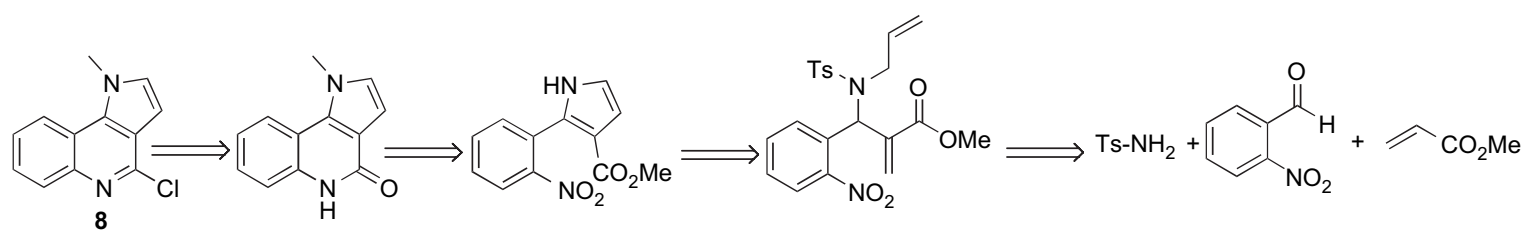

Scheme 1. Retrosynthesis of imidoyl chloride $\mathbf{8}$.

\section{Results and discussion}

Scheme 2 describes the synthesis of the imidoyl chloride unit. ${ }^{8}$

The first step in this strategy was the synthesis of the unsaturated $\beta$-aminoester 1 through the 3-component one-pot aza-version of the Baylis-Hillman reaction..$^{18,31-41}$ The reaction was performed using a nitrobenzaldehyde excess and methylacrylate, in the presence of DABCO, molecular sieves, titanium isopropoxide as a Lewis acid, and $i-\mathrm{PrOH}$ as solvent to yield $64 \%$ of 1 along with $30 \%$ of the corresponding $\beta$-hydroxyester. The $\beta$-aminoester 1 recovered by crystallization in a mixture of dichloromethane, diethylether, and pentane was reacted with allyl bromide ${ }^{42}$ in the presence of $\mathrm{K}_{2} \mathrm{CO}_{3}$ in DMF to yield quantitatively the corresponding diene 2 . The reaction was performed either at room temperature within $12 \mathrm{~h}$ or heating under microwave irradiation at $100{ }^{\circ} \mathrm{C}$ within $10 \mathrm{~min}$ without affecting the yield. Diene 2 was used in the next step without further purification. Pyrroline $\mathbf{3}$ was formed using ringclosing metathesis ${ }^{43}$ known to be an efficient method for the synthesis of heterocyclic structures from linear precursors. While cyclization of the diene $\mathbf{2}$ was complete within $12 \mathrm{~h}$ at room

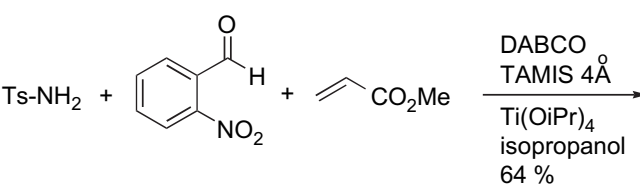

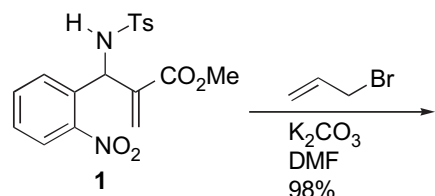<smiles>C=CCN([13CH3])C(C(=O)OC)c1ccccc1[N+](=O)[O-]</smiles>
$98 \%$<smiles>COc1ccn(C)c1-c1ccccc1N</smiles>

6

$\mathrm{CH}_{3} \mathrm{COOH}$ sec-Butanol $\mathrm{MW} / 100^{\circ} \mathrm{C}$ $98 \%$

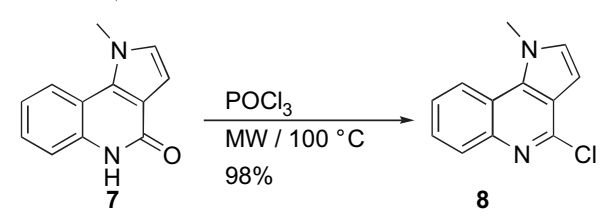<smiles>COC(=O)c1cc[nH]c1-c1ccc(C(C)(C)C)cc1[N+](=O)[O-]</smiles>

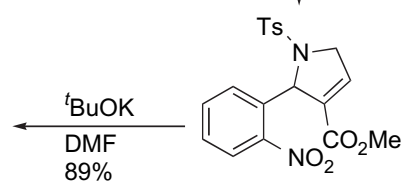

Scheme 2. Procedure for the preparation of imidoyl chloride. ${ }^{8}$ 

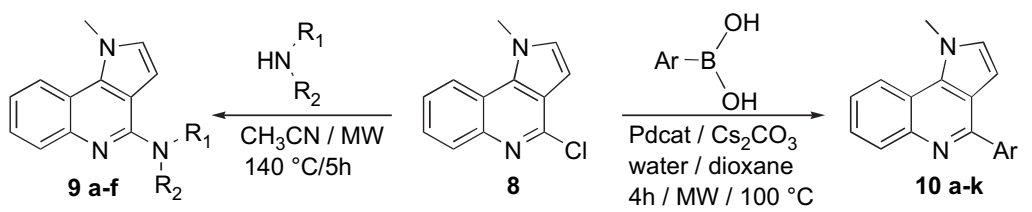

Scheme 3. Amination and arylation of imidoyl chloride skeleton.

temperature using $10 \%$ second generation Grubbs' catalyst with $87 \%$ yield, it could be conveniently accelerated by microwave using only $4 \%$ of the catalyst. Under these conditions (microwaves, $100{ }^{\circ} \mathrm{C}$, $\mathrm{CH}_{2} \mathrm{Cl}_{2}$ ) completion of the cyclization was reached within $2 \mathrm{~h}$ yielding $84 \%$ of 3 . An interesting point is that the cyclization of 2 was slower than in the case of other similar dienes without a nitro group. ${ }^{18}$ This result might be due to the coordinating effect ${ }^{44-46}$ between the nitro substituent and the ruthenium catalyst. The next step was cleavage of the tosyl group. ${ }^{17,47,48}$ Using $t$-BuOK in DMF at room temperature, $89 \%$ of substituted pyrrole 4 was obtained within 2 h via elimination-aromatization. The pyrrole 4 was reacted with methyl iodide ${ }^{42}$ in the presence of $\mathrm{Cs}_{2} \mathrm{CO}_{3}$ in DMF to yield the protected pyrrole $\mathbf{5}$ in quantitative yield. It should be noted that conversion was incomplete when $\mathrm{K}_{2} \mathrm{CO}_{3}$ was used instead of $\mathrm{Cs}_{2} \mathrm{CO}_{3}$. Reduction ${ }^{10}$ with $\mathrm{Pd} / \mathrm{C}$ under $\mathrm{H}_{2}$ atmosphere yielded the stable amine derivative $\mathbf{6}$ in excellent yield after simple filtration over Celite and evaporation of the solvent. Cyclization of the latter amine was first carried out using sodium hydride in THF. The conversion was complete but the cyclic product was difficult to recover since it was soluble only in DMSO. Finally a solution of $\mathbf{6}$ in sec-butanol in the presence of $1 \%$ acetic acid ${ }^{49}$ was irradiated with microwaves for $4 \mathrm{~h}$ at $100{ }^{\circ} \mathrm{C}$ to afford the cyclic unit 7 in quantitative yield without further purifications. The key step in this strategy was the introduction of chlorine in the 4-position. This was achieved by transformation of the amide function into an imidoyl chloride using phosphorus oxychloride. ${ }^{11}$ The reaction was carried out using classical conditions (refluxing 7 in phosphorus oxychloride for $7 \mathrm{~h}$ ) or activation by microwave irradiation for only $15 \mathrm{~min}$.

In contrast to what has been emphasized in the literature,, 90 the introduction of chlorine atom together with microwave-activated transformations allowed us to introduce successfully different substituent in the 4-position of the skeleton. These reactions are highlighted in Scheme 3.

Compound $\mathbf{8}$ was used for the preparation of substituted pyrroloquinolines. Reactions with amines and boronic acids were studied. The first tested reaction was the nucleophilic substitution of the chlorine atom by amines. Preliminary tests were carried out using different amines as nucleophiles and $\mathrm{NaH}$ as a base in THF but no product could be obtained under these conditions. Then the procedure described by Campiani ${ }^{11}$ and co-workers was tried; a mixture of imidoyl chloride $\mathbf{8}$ and amine in ethylene glycol was heated using classical heating or activation by microwave irradiations. In both cases the reaction was incomplete. In sharp contrast, by using $\mathrm{CH}_{3} \mathrm{CN}$ instead of ethylene glycol, completion of all the reactions was reached, even with less nucleophilic pyrrole. The reaction gave good to excellent yields with various amines. Results are summarized in Table 1. A lower yield was obtained in the case of morpholine (entry 4) due to the difficulty in separating the expected product 9d from the starting amine.

The chlorine atom could be substituted by cyclic secondary amines such as pyrrolidine, morpholine or piperazine. Benzylamine gave also good yield of the expected product. As a last example, pyrrole reacted with $\mathbf{8}$ to give a pyrrole-substituted pyrroloquinoline.

The second investigated reaction was the Suzuki coupling of the imidoyl chloride with a boronic acid. First, $\mathrm{Pd}(\mathrm{OAc})_{2}, \mathrm{PPh}_{3}$ in the presence of $\mathrm{K}_{2} \mathrm{CO}_{3}$ in a mixture of water/dioxane (1:1) was used as
Table 1

Amination ${ }^{\mathrm{a}}$ products of imidoyl chloride $\mathbf{8}$

\begin{tabular}{llll}
\hline Entry & Amine & Product & Yield (\%) \\
\hline 1 & Pyrrolidine & 9a & 95 \\
2 & Piperidine & 9b & 85 \\
3 & 4-Methylpiperazine & 9 9c & 80 \\
4 & Morpholine & 9d & 63 \\
5 & Benzylamine & 9e & 73 \\
6 & Pyrrole & 9f & 87 \\
\hline
\end{tabular}

${ }^{\text {a }} \mathrm{CH}_{3} \mathrm{CN}, \mathrm{MW}, 140{ }^{\circ} \mathrm{C}, 5 \mathrm{~h}$.

a catalytic system..$^{2,23}$ The reaction was heated from 80 to $180{ }^{\circ} \mathrm{C}$ and monitored by HPLC. After $2 \mathrm{~h}$ at $180^{\circ} \mathrm{C}$ the boronic acid disappeared completely, although some of the imidoyl chloride remained. The reaction was complete by addition of one more equivalent of boronic acid. A column chromatography was necessary to obtain the pure final product. By using the PEPPSI ${ }^{51}$ precatalyst (Pyridine-Enhanced Precatalyst Preparation Stabilization and Initiation) instead of $\mathrm{Pd}(\mathrm{OAc})_{2}$, and in the presence of $\mathrm{Cs}_{2} \mathrm{CO}_{3}$, the desired compounds were obtained by heating at $100{ }^{\circ} \mathrm{C}$ under microwaves. These products were obtained in pure form after usual work-up without further purification. PEPPSI is a Pd complex stabilized by NHC ( $N$-Heterocyclic Carbene) and pyridine ligands. They are known to allow rapid and quantitative $\mathrm{C}-\mathrm{C}$ bond formation in Suzuki crosscoupling reactions. ${ }^{51}$ These results suggest that bulky NHC ligands lead to fast reductive elimination, with no side reactions or catalyst decomposition similarly with bulky phosphines. ${ }^{52,53}$ This catalyst seemed well adapted to Pd-catalyzed microwave-enhanced reactions. Results are summarized in Table 2.

Various substituents can be borne by the boronic acid. The position of the substituent on the aromatic ring did not seem to influence the outcome of the reaction since the more hindered $o$-tolyl boronic acid (entry 2) or 0 -anisyl boronic acid (entry 5) gave essentially the same yield of product as in the case of $m$ - or $p$-tolyl boronic acid (entries 3 and 4). Fluorinated quinolines could also be synthesized (entries 6 and 7). Finally this method provided access to a variety of polyaromatic compounds (entries 8-11).

Often, the introduction of specific substituents other than simple alkyl ones in the 4-position on the performed skeleton required laborious steps coupled with drastic experimental conditions. ${ }^{10,16}$ To our knowledge, this is the first time that introduction of various substituents was carried out without any problems.

Table 2

Arylation $^{\mathrm{a}}$ of imidoyl chloride

\begin{tabular}{llll}
\hline Entry & Aryl & Product & Yield (\%) \\
\hline 1 & Phenyl & $\mathbf{1 0 a}$ & 84 \\
2 & o-Tolyl & $\mathbf{1 0 b}$ & 70 \\
3 & m-Tolyl & $\mathbf{1 0 c}$ & 74 \\
4 & p-Tolyl & $\mathbf{1 0 d}$ & 73 \\
5 & 2-Methoxyphenyl & $\mathbf{1 0 e}$ & 75 \\
6 & 4-Fluorophenyl & $\mathbf{1 0 f}$ & 90 \\
7 & 4-Trifluromethoxyphenyl & $\mathbf{1 0 g}$ & 76 \\
8 & Naphthalen-1-yl & $\mathbf{1 0 h}$ & 84 \\
9 & Biphenyl & $\mathbf{1 0 i}$ & 80 \\
10 & Benzofuran-2-yl & $\mathbf{1 0 j}$ & 91 \\
11 & 1,2,3,4-Tetrahydro-1,1,4,4-tetramethylnaphthalen-6-yl & $\mathbf{1 0 k}$ & 73 \\
\hline
\end{tabular}

a Water/dioxane (1:1), PEPPSI (0.02 equiv), $\mathrm{Cs}_{2} \mathrm{CO}_{3}$ ( 1.5 equiv), $\mathrm{MW}, 100{ }^{\circ} \mathrm{C}, 4 \mathrm{~h}$. 


\section{Conclusion}

A new approach to the synthesis of a series of 4-amino-1methyl-4-1H-pyrrolo-[3,2-c]quinoline and 4-aryl-1-methyl-4- $1 H$ pyrrolo-[3,2-c]quinoline derivatives is described. This approach is based on high yielding steps, which do not need cumbersome purifications. In contrast to previously described methods, this new pathway allowed convenient introduction onto the 4-position the title ring system of a variety of amines and aryl compounds. This is largely due the use of microwave activation during several steps of the synthesis.

\section{Experimental section}

\subsection{Methyl 2-((2-nitrophenyl)(p-toluenesulfonylamino)- methyl)acrylate (1)}

To a mixture of $p$-toluenesulfonamide ( $9 \mathrm{~g}, 52.6 \mathrm{mmol}$ ), DABCO (885 mg, $7.9 \mathrm{mmol}$ ), and molecular sieves (4 Å, $10.5 \mathrm{~g}, 200 \mathrm{mg} /$ mmol of substrate) in $27 \mathrm{ml}$ of 2-propanol were added 2-nitrobenzaldehyde $(11.9 \mathrm{~g}, 78.8 \mathrm{mmol})$, methyl acrylate $(7.44 \mathrm{~g}$, $86.7 \mathrm{mmol})$, and titanium isopropoxide $(0.3 \mathrm{~g}, 1.05 \mathrm{mmol})$. The reaction mixture was stirred at room temperature overnight and filtered over Celite. The Celite was rinsed three times with $\mathrm{CH}_{2} \mathrm{Cl}_{2}$. The solvent was evaporated and the residue was dissolved in AcOEt, neutralized with aqueous $\mathrm{KHSO}_{4}(10 \%)$, and washed with saturated $\mathrm{NaHCO}_{3}$ and brine. The organic layer was dried over $\mathrm{MgSO}_{4}$, filtered, and evaporated. Hot crystallization in a 5:5:1 mixture of pentane, diethylether, and dichloromethane afforded $13 \mathrm{~g} \mathrm{(63 \% )} \mathrm{of}$ $\beta$-aminoester $\mathbf{1}$.

Mp 109-111 ${ }^{\circ} \mathrm{C} ;{ }^{1} \mathrm{H}$ NMR $\left(\mathrm{CDCl}_{3}, \mathrm{Me}_{4} \mathrm{Si}\right) \delta 2.41$ (s, 3H), 3.58 (s, $3 \mathrm{H}), 5.69(\mathrm{~s}, 1 \mathrm{H}), 5.98(\mathrm{~d}, 1 \mathrm{H}, J=8.62 \mathrm{~Hz}), 6.11(\mathrm{~d}, 1 \mathrm{H}, J=8.62 \mathrm{~Hz}), 6.23$ (s, 1H), 7.23-7.29 (m, 2H), 7.38-7.41 (m, 1H), 7.52-7.57 (m, 1H), 7.70 $(\mathrm{d}, 3 \mathrm{H}, J=8.12 \mathrm{~Hz}), 7.84(\mathrm{~d}, 1 \mathrm{H}, J=8.06 \mathrm{~Hz}) ;{ }^{13} \mathrm{C} \mathrm{NMR}\left(\mathrm{CDCl}_{3}, \mathrm{Me}_{4} \mathrm{Si}\right)$ $\delta$ 21.1, 52.1, 54.4, 124.5, 127.2, 128.8, 129.1, 129.6, 130.1, 133.1, 133.4, 137.1, 137.4, 143.6, 148.0, 165.4; ESIMS $m / z$ 781.25 $(2 \mathrm{M}+\mathrm{H})^{+}, 391.1$ $(\mathrm{M}+\mathrm{H})^{+}, 220.00(\mathrm{M}-\mathrm{TsNH})^{+}$; HRMS calcd for $\mathrm{C}_{18} \mathrm{H}_{19} \mathrm{O}_{6} \mathrm{~N}_{2} \mathrm{~S}$, 391.0964; found, 391.0978.

\subsection{Methyl 2-((N-allyl- $N$-tosylamino)(2-nitrophenyl)- methyl)acrylate (2)}

To a mixture of $\beta$-aminoester 1 ( $4 \mathrm{~g}, 10.2 \mathrm{mmol}$ ) and $\mathrm{K}_{2} \mathrm{CO}_{3}(14 \mathrm{~g}$, $102 \mathrm{mmol}$ ) in $140 \mathrm{ml}$ of DMF was added allylbromide $(2.99 \mathrm{~g}$, $108 \mathrm{mmol}$ ). The reaction mixture was stirred overnight at room temperature, then filtered and diluted with AcOEt. The organic layer was successively washed with water and brine, dried over $\mathrm{MgSO}_{4}$, filtered, and evaporated, to yield $4.29 \mathrm{~g}$ (98\%) of $N$-allyl- $\beta$ aminoester 2.

Mp 83-85 ${ }^{\circ} \mathrm{C} ;{ }^{1} \mathrm{H}$ NMR $\left(\mathrm{CDCl}_{3}, \mathrm{Me}_{4} \mathrm{Si}\right) \delta 2.33(\mathrm{~s}, 3 \mathrm{H}), 3.46(\mathrm{~s}, 3 \mathrm{H})$, $4.01\left(\mathrm{dd}, 1 \mathrm{H}, J=6.57 \mathrm{~Hz}, J^{\prime}=6.43 \mathrm{~Hz}\right), 8.03$ (dd, $1 \mathrm{H}, J=6.57 \mathrm{~Hz}$, $\left.J^{\prime}=6.43 \mathrm{~Hz}\right), 4.88-4.89(\mathrm{~m}, 1 \mathrm{H}), 4.90(\mathrm{~d}, 1 \mathrm{H}, J=1.23 \mathrm{~Hz}), 5.40-5.49$ $(\mathrm{m}, 2 \mathrm{H}), 6.36(\mathrm{~s}, 1 \mathrm{H}), 6.37$ (s, 1H), 7.15-7.18 (m, 2H), 7.36-7.41 (m, 1H), 7.54-7.59 (m, 3H), $7.69(\mathrm{~d}, 1 \mathrm{H}, J=7.71 \mathrm{~Hz}), 7.85(\mathrm{~d}, 1 \mathrm{H}$, $J=8.08 \mathrm{~Hz}) ;{ }^{13} \mathrm{C}$ NMR $\left(\mathrm{CDCl}_{3}, \mathrm{Me}_{4} \mathrm{Si}\right) \delta 43.1,50.8,52.1,58.5,118.7$, 125.3, 127.7, 128.7, 129.3, 129.6, 130.5, 131.5, 132.9, 133.2, 133.7, $134.4,137.8,138.3,143.3,148.0,165.4$; ESIMS $m / z$ 883.4 $(2 \mathrm{M}+\mathrm{Na})^{+}$, $453.2(\mathrm{M}+\mathrm{Na})^{+}, \quad 431.2(\mathrm{M}+\mathrm{H})^{+}, \quad 220.4\left(\mathrm{M}-\mathrm{TsNC}_{3} \mathrm{H}_{5}\right)^{+}, \quad 188.4$ $\left(\mathrm{M}-\mathrm{TsNC}_{3} \mathrm{H}_{5}-\mathrm{OMe}\right)^{+}$; HRMS calcd for $\mathrm{C}_{21} \mathrm{H}_{23} \mathrm{~N}_{2} \mathrm{O}_{6} \mathrm{~S}$, 431.1277; found, 431.1272 .

\subsection{Methyl 2,5-dihydro-2-(2-nitrophenyl)-1-tosyl-1H- pyrrole-3-carboxylate (3)}

Conditions $A . \mathrm{Cl}_{2}\left(\mathrm{PCy}_{3}\right)-(\mathrm{IMes}) \mathrm{Ru}=\mathrm{CHPh}(0.1 \mathrm{~g}, 0.32 \mathrm{mmol})$ was added to a solution of $N$-allyl- $\beta$-aminoester $(1 \mathrm{~g}, 2.32 \mathrm{mmol})$ in
$232 \mathrm{ml}$ of $\mathrm{CH}_{2} \mathrm{Cl}_{2}$, and the mixture was stirred overnight at room temperature. Then $0.48 \mathrm{ml}$ of DMSO (50 equiv/Ru) was added and the mixture was stirred for $24 \mathrm{~h}$ at room temperature. The solvent was evaporated under vacuum. Column chromatography over silica gel and $\mathrm{Et}_{2} \mathrm{O} /$ cyclohexane (1:9 to 3:7) as developing solvent affords $0.81 \mathrm{~g}(87 \%)$ of the desired 2,5-dihydropyrrole 3.

Conditions $B$. A solution of $\mathrm{Cl}_{2}\left(\mathrm{PCy}_{3}\right)$-(IMes) $\mathrm{Ru}=\mathrm{CHPh}(6.4 \mu \mathrm{mol})$ in $\mathrm{CH}_{2} \mathrm{Cl}_{2}(3 \mathrm{ml})$ was added to a solution of $N$-allyl- $\beta$-aminoester (500 $\mathrm{mg}, 1.16 \mathrm{mmol}$ ) in $\mathrm{CH}_{2} \mathrm{Cl}_{2}(9 \mathrm{ml})$, and the mixture was irradiated by microwaves for $2 \mathrm{~h}$ at $150{ }^{\circ} \mathrm{C}$. Then $165 \mu \mathrm{l}$ of DMSO ( 50 equiv/ $\mathrm{Ru}$ ) was added and the mixture was stirred for an additional time of $24 \mathrm{~h}$. The solvent was dried under vacuum. Column chromatography over silica gel and $\mathrm{Et}_{2} \mathrm{O} /$ cyclohexane (1:9 to $\left.3: 7\right)$ as developing solvent affords $380 \mathrm{mg}(82 \%)$ of the desired 2,5-dihydropyrrole 3.

Mp $125-127{ }^{\circ} \mathrm{C} ;{ }^{1} \mathrm{H}$ NMR $\left(\mathrm{CDCl}_{3}, \mathrm{Me}_{4} \mathrm{Si}\right) \delta 2.36(\mathrm{~s}, 3 \mathrm{H}), 3.45(\mathrm{~s}$, $3 \mathrm{H}), 4.29(\mathrm{td}, 1 \mathrm{H}, J=2.68 \mathrm{~Hz}), 4.54(\mathrm{ddd}, 1 \mathrm{H}, J=6 \mathrm{~Hz}), 6.61-6.64(\mathrm{~m}$, $1 \mathrm{H}), 6.68(\mathrm{t}, 1 \mathrm{H}, J=2 \mathrm{~Hz}), 7.27(\mathrm{~d}, 2 \mathrm{H}, J=8.27 \mathrm{~Hz}), 7.31-7.36(\mathrm{~m}, 1 \mathrm{H})$, $7.48-7.50\left(\mathrm{t}, 2 \mathrm{H}, J=4.23 \mathrm{~Hz}, J^{\prime}=3.8 \mathrm{~Hz}\right), 7.74(\mathrm{~d}, 2 \mathrm{H}, J=8.27 \mathrm{~Hz}), 7.83$ $(\mathrm{d}, 1 \mathrm{H}, J=8.22 \mathrm{~Hz}) ;{ }^{13} \mathrm{C} \mathrm{NMR}\left(\mathrm{CDCl}_{3}, \mathrm{Me}_{4} \mathrm{Si}\right) \delta 21.6,52.1,55.7,62.3$, 124.6, 127.8, 128.6, 129.7, 130.0, 133.1, 133.4, 135.1, 135.7, 136.6, 144.2, 148.7, 161.6; ESIMS $m / z 827(2 \mathrm{M}+\mathrm{Na})^{+}, 425(\mathrm{M}+\mathrm{Na})^{+}, 403.2$ $(\mathrm{M}+\mathrm{H})^{+}$; HRMS calcd for $\mathrm{C}_{19} \mathrm{H}_{19} \mathrm{~N}_{2} \mathrm{O}_{6} \mathrm{~S}, 403.0964$; found, 403.0970 .

\subsection{Methyl 2-(2-nitrophenyl)-1H-pyrrole-3-carboxylate (4)}

To a stirred solution of 2,5-dihydropyrrole $(2 \mathrm{~g}, 4.97 \mathrm{mmol})$ in $50 \mathrm{ml}$ of DMF was added $t$-BuOK $(2.78 \mathrm{~g}, 24.8 \mathrm{mmol})$. The mixture was stirred at room temperature for $2 \mathrm{~h}$, then $350 \mathrm{ml}$ of AcOEt was added and the mixture was neutralized with a $1 \%$ aqueous solution of $\mathrm{KHSO}_{4}$ and washed with $\mathrm{NaHCO}_{3}$ saturated water, and brine. The organic layer was dried over $\mathrm{MgSO}_{4}$, filtered, and evaporated. Column chromatography over silica gel and $\mathrm{Et}_{2} \mathrm{O} /$ cyclohexane (1:9 to $1: 1)$ as developing solvent yields $1.09 \mathrm{~g}(89 \%)$ of 4 .

${ }^{1} \mathrm{H} \mathrm{NMR}\left(\mathrm{CDCl}_{3}, \mathrm{Me}_{4} \mathrm{Si}\right) \delta 3.55(\mathrm{~s}, 3 \mathrm{H}), 6.64(\mathrm{t}, 1 \mathrm{H}, J=2.8 \mathrm{~Hz}), 6.76$ $(\mathrm{t}, 1 \mathrm{H}, J=2.8 \mathrm{~Hz}), 7.37(\mathrm{~d}, 1 \mathrm{H}, J=1.5 \mathrm{~Hz}), 7.44-7.49(\mathrm{~m}, 1 \mathrm{H}), 7.52-7.58$ $(\mathrm{m}, 1 \mathrm{H}), 7.94(\mathrm{~d}, 1 \mathrm{H}, J=1.5 \mathrm{~Hz}), 8.6(\mathrm{~s}, 1 \mathrm{H}) ;{ }^{13} \mathrm{C} \mathrm{NMR}\left(\mathrm{CDCl}_{3}, \mathrm{Me}_{4} \mathrm{Si}\right)$ $\delta$ 51.0, 111.4, 113.4, 118.7, 124.4, 127.3, 129.5, 131.4, 132.4, 132.5, 149.5, 164.8; ESIMS $m / z \quad 215.1\left(\mathrm{M}-\mathrm{OCH}_{3}\right)^{+}, \quad 247.2(\mathrm{M}+\mathrm{H})^{+}, \quad 264.2$ $\left(\mathrm{M}+\mathrm{H}_{2} \mathrm{O}\right)^{+}, 269.2(\mathrm{M}+\mathrm{Na})^{+}$; HRMS calcd for $\mathrm{C}_{12} \mathrm{H}_{11} \mathrm{~N}_{2} \mathrm{O}_{4}, 247.0719$; found, 247.0738.

\subsection{Methyl 1-methyl-2-(2-nitrophenyl)-1H-pyrrole-3- carboxylate (5)}

To a mixture of $4(1 \mathrm{~g}, 4.06 \mathrm{mmol})$ and $\mathrm{Cs}_{2} \mathrm{CO}_{3}(5.29 \mathrm{~g}$, $16.25 \mathrm{mmol}$ ) in $250 \mathrm{ml}$ of DMF was added methyliodide $(2.3 \mathrm{~g}$, $16.25 \mathrm{mmol}$ ). The reaction mixture was stirred overnight at room temperature, the solvent was evaporated, and the residue was diluted with AcOEt. The organic layer was washed with water and brine, dried over $\mathrm{MgSO}_{4}$, filtered, and evaporated, to yield $1 \mathrm{~g}(98 \%)$ of 5.

Mp 125-127 ${ }^{\circ} \mathrm{C} ;{ }^{1} \mathrm{H} N M R\left(\mathrm{CDCl}_{3}, \mathrm{Me}_{4} \mathrm{Si}\right) \delta 3.35(\mathrm{~s}, 3 \mathrm{H}), 3.49(\mathrm{~s}, 3 \mathrm{H})$, $6.56(\mathrm{~d}, 1 \mathrm{H}, J=2.97 \mathrm{~Hz}), 6.63(\mathrm{~d}, 1 \mathrm{H}, J=2.97 \mathrm{~Hz}), 7.31(\mathrm{dd}, 1 \mathrm{H}, J=1.6 \mathrm{~Hz}$, $\left.J^{\prime}=1.6 \mathrm{~Hz}\right), 7.50-7.64(\mathrm{~m}, 1 \mathrm{H}), 7.74(\mathrm{~d}, 1 \mathrm{H}, J=8.27 \mathrm{~Hz}), 8.03(\mathrm{dd}, 1 \mathrm{H}$, $\left.J=1.3 \mathrm{~Hz}, J^{\prime}=1.3 \mathrm{~Hz}\right) ;{ }^{13} \mathrm{CNMR}\left(\mathrm{CDCl}_{3}, \mathrm{Me}_{4} \mathrm{Si}\right) \delta 31.9,50.8,110.2,113.5$, $122.9,124.3,127.8,129.8,132.8,133.0,133.2,149.9,164.6$; ESIMS $m / z$ $283.2(\mathrm{M}+\mathrm{Na})^{+}, 261.2(\mathrm{M}+\mathrm{H})^{+}, 229.2\left(\mathrm{M}-\mathrm{OCH}_{3}\right)^{+}$; HRMS calcd for $\mathrm{C}_{13} \mathrm{H}_{13} \mathrm{~N}_{2} \mathrm{O}_{4}, 261.0875$; found, 261.0870 .

\subsection{Methyl 1-methyl-2-(2-aminophenyl)-1H-pyrrole-3- carboxylate (6)}

To a solution of $5(1 \mathrm{~g}, 3.84 \mathrm{mmol})$ in methanol $(200 \mathrm{ml})$ was added $10 \%(0.35 \mathrm{~g})$ of $\mathrm{Pd}(\mathrm{OH})_{2} / \mathrm{C}$. The mixture was stirred for $2 \mathrm{~h}$ at room temperature under $\mathrm{H}_{2}$ atmosphere. The crude product was 
filtered over Celite, washed with warmed methanol, and evaporated to afford $0.86 \mathrm{~g}(98 \%)$ of the title compound as a white solid.

Mp 113-115 ${ }^{\circ} \mathrm{C} ;{ }^{1} \mathrm{H}$ NMR $\left(\mathrm{CDCl}_{3}, \mathrm{Me}_{4} \mathrm{Si}\right) \delta 3.33$ (s, 3H), 3.53 (s, $2 \mathrm{H}), 3.59(\mathrm{~s}, 3 \mathrm{H}), 6.59-6.62(\mathrm{~m}, 2 \mathrm{H}), 6.69-6.77(\mathrm{~m}, 2 \mathrm{H}), 6.97(\mathrm{dd}, 1 \mathrm{H}$ $\left.J=J^{\prime}=1.4 \mathrm{~Hz}\right), 7.12-7.19(\mathrm{~m}, 1 \mathrm{H}) ;{ }^{13} \mathrm{C} \mathrm{NMR}\left(\mathrm{CDCl}_{3}, \mathrm{Me}_{4} \mathrm{Si}\right) \delta 34.3,50.9$, 110.0, 113.6, 115.5, 117.4, 118.2, 122.5, 129.9, 131.4, 135.5, 145.8, 165.0; ESIMS $m / z$ 461.1 $(2 \mathrm{M}+\mathrm{H})^{+}, 253.1(\mathrm{M}+\mathrm{Na})^{+}, 231.1(\mathrm{M}+\mathrm{H})^{+}, 199.1$ $\left(\mathrm{M}-\mathrm{OCH}_{3}\right)^{+}$; HRMS calcd for $\mathrm{C}_{13} \mathrm{H}_{15} \mathrm{~N}_{2} \mathrm{O}_{2}, 231.1045$; found, 231.1040.

\subsection{1-Methyl-1H-pyrrolo-[3,2-c]quinolin-4(5H)-one (7)}

To a solution of $6(0.25 \mathrm{~g}, 1.08 \mathrm{mmol})$ in sec-butanol $(10 \mathrm{ml})$, was added $100 \mu \mathrm{l}$ of acetic acid. The mixture was irradiated with microwaves for $4 \mathrm{~h}$ at $100{ }^{\circ} \mathrm{C}$. The solvent was evaporated under reduced pressure to yield $0.21 \mathrm{~g}(98 \%)$ of the product as a white solid.

$\mathrm{Mp} 285-289^{\circ} \mathrm{C} ;{ }^{1} \mathrm{H}$ NMR $\left(\mathrm{CD}_{3} \mathrm{OD}, \mathrm{Me}_{4} \mathrm{Si}\right) \delta 4.95$ (s, 3H), 7.42 (d, $1 \mathrm{H}, J=2.9 \mathrm{~Hz}), 7.99-8.04(\mathrm{~m}, 2 \mathrm{H}), 7.50-8.25(\mathrm{~m}, 2 \mathrm{H}), 8.96(\mathrm{~d}, 1 \mathrm{H}$, $J=8.08 \mathrm{~Hz}), 12.08(\mathrm{~s}, 1 \mathrm{H}) ;{ }^{13} \mathrm{C} \mathrm{NMR}\left(\mathrm{CD}_{3} \mathrm{OD}, \mathrm{Me}_{4} \mathrm{Si}\right) \delta 40.2,106.5$, 116.2, 118.7, 119.0, 123.8, 124.1, 129.5, 131.7, 135.6, 139.1, 161.9; ESIMS $m / z \quad 419.1(2 \mathrm{M}+\mathrm{Na})^{+}, 397.1(2 \mathrm{M}+\mathrm{H})^{+}, 221.1(\mathrm{M}+\mathrm{Na})^{+}, 199.1$ $(\mathrm{M}+\mathrm{H})^{+}$; HRMS calcd for $\mathrm{C}_{12} \mathrm{H}_{11} \mathrm{~N}_{2} \mathrm{O}, 199.0871$; found, 199.0874 .

\subsection{4-Chloro-1-methyl-1H-pyrrolo-[3,2-c]quinoline (8)}

Thermal conditions. A mixture of quinolinone 7 (500 mg, $2.52 \mathrm{mmol}$ ) and freshly distilled $\mathrm{POCl}_{3}(30 \mathrm{ml})$ was refluxed for $7 \mathrm{~h}$. The cooled crude product was poured into ice-water and the precipitate was extracted with $\mathrm{CH}_{2} \mathrm{Cl}_{2}(3 \times 40 \mathrm{ml})$. The combined extracts were dried over $\mathrm{MgSO}_{4}$ and concentrated under reduced pressure. The product was recovered as a white solid. The precipitate in the aqueous phase was filtered and washed with water. The solid fractions were combined yielding $530 \mathrm{mg}$ (98\%) of imidoyl chloride $\mathbf{8}$.

Microwave irradiation. A mixture of quinolinone 7 (500 $\mathrm{mg}$, $2.52 \mathrm{mmol})$ and freshly distilled $\mathrm{POCl}_{3}(10 \mathrm{ml})$ was irradiated by microwave for $15 \mathrm{~min}$ at $140{ }^{\circ} \mathrm{C}$. Then the crude product was poured into ice-water and the precipitate was extracted with $\mathrm{CH}_{2} \mathrm{Cl}_{2}(3 \times 40 \mathrm{ml})$. The combined extracts were dried over $\mathrm{MgSO}_{4}$ and concentrated under reduced pressure. The product was recovered as a white solid. The precipitate in aqueous phase was filtered and washed with water. The solid fractions were combined to yield $530 \mathrm{mg}(98 \%)$ of imidoyl chloride $\mathbf{8}$.

Mp 83-85 ${ }^{\circ} \mathrm{C} ;{ }^{1} \mathrm{H}$ NMR $\left(\mathrm{CDCl}_{3}, \mathrm{Me}_{4} \mathrm{Si}\right) \delta 4.23(\mathrm{~s}, 3 \mathrm{H}), 6.73(\mathrm{~d}, 1 \mathrm{H}$, $J=3.1 \mathrm{~Hz}$ ), $7.08(\mathrm{~d}, 1 \mathrm{H}, J=3.1 \mathrm{~Hz}), 7.51-7.61(\mathrm{~m}, 2 \mathrm{H}), 8.22(\mathrm{~d}, 1 \mathrm{H}$, $J=7.6 \mathrm{~Hz}$ ), $8.30\left(\mathrm{dd}, 1 \mathrm{H}, J=1.74 \mathrm{~Hz}, J=1.06 \mathrm{~Hz}\right.$ ); ${ }^{13} \mathrm{C}$ NMR (DMSO, $\left.\mathrm{Me}_{4} \mathrm{Si}\right) \delta$ 37.6, 101.2, 118.1, 119.7, 121.3, 126.3, 127.0, 128.5, 131.8, 134.6, 142.7, 144.0; ESIMS $m / z 217.1(\mathrm{M}+\mathrm{H})^{+}$; HRMS calcd for $\mathrm{C}_{12} \mathrm{H}_{10} \mathrm{~N}_{2} \mathrm{Cl}$, 217.0533; found, 217.0548 .

\subsection{General procedure for the synthesis of 4-amino-1- methyl-1H-pyrrolo-[3,2-c]quinolines 9a-f}

To a solution of imidoyl chloride $\mathbf{8}\left(20 \mathrm{mg}, 9.25 \times 10^{-2} \mathrm{mmol}\right)$ in acetonitrile $(2 \mathrm{ml})$ was added 5 equiv of amine, then the mixture was irradiated under microwaves for $5 \mathrm{~h}$ at $140{ }^{\circ} \mathrm{C}$. The mixture was diluted with diethylether $(20 \mathrm{ml})$, washed with water $(2 \times 10 \mathrm{ml})$, dried over $\mathrm{MgSO}_{4}$, and concentrated under reduced pressure to obtain the title compounds $\mathbf{9 a}-\mathbf{e}$, which were purified by silica gel chromatography.

\subsubsection{1-Methyl-4-(pyrrolidin-1'-yl)-1H-pyrrolo-[3,2-c]- quinoline (9a)}

The crude product was purified by silica gel chromatography $\left(\mathrm{CH}_{2} \mathrm{Cl}_{2} / \mathrm{MeOH}=100: 1\right)$ to yield $22.09 \mathrm{mg}$ (95\%) of the title compound.
${ }^{1} \mathrm{H}$ NMR $\left(\mathrm{CD}_{3} \mathrm{OD}, \mathrm{Me}_{4} \mathrm{Si}\right) \delta$ 2.01-2.06 (m, 4H), $3.79(\mathrm{t}, 4 \mathrm{H}$, $J=6.4 \mathrm{~Hz}), 4.06(\mathrm{~s}, 3 \mathrm{H}), 6.84(\mathrm{~d}, 1 \mathrm{H}, J=3.2 \mathrm{~Hz}), 7.12(\mathrm{~d}, 1 \mathrm{H}, J=3.2 \mathrm{~Hz})$, 7.27 (t, $1 \mathrm{H}, J=7.3 \mathrm{~Hz}$ ), 7.41 (t, $1 \mathrm{H}, J=7.3 \mathrm{~Hz}), 7.60$ (d, $1 \mathrm{H}, J=8.3 \mathrm{~Hz}$ ), $8.15(\mathrm{~d}, 1 \mathrm{H}, J=8.3 \mathrm{~Hz}) ;{ }^{13} \mathrm{C} \mathrm{NMR}\left(\mathrm{CD}_{3} \mathrm{OD}, \mathrm{Me}_{4} \mathrm{Si}\right) \delta 26.4,38.8,51.2$, 106.4, 111.7, 115.9, 121.8, 122.4, 124.5, 128.9, 131.1, 136.1, 150.6, 158.0; ESIMS $m / z 252.0(\mathrm{M}+\mathrm{H})^{+}$; HRMS calcd for $\mathrm{C}_{16} \mathrm{H}_{18} \mathrm{~N}_{3}, 252.1501$; found, 252.1500 .

\subsubsection{1-Methyl-4-(piperidin-1'-yl)-1H-pyrrolo-[3,2-c]- quinoline (9b)}

The crude product was purified by silica gel chromatography $\left(\mathrm{CH}_{2} \mathrm{Cl}_{2} / \mathrm{MeOH}=100: 1\right)$ to yield $20.9 \mathrm{mg}(85 \%)$ of the title compound.

${ }^{1} \mathrm{H}$ NMR $\left(\mathrm{CD}_{3} \mathrm{OD}, \mathrm{Me}_{4} \mathrm{Si}\right) \delta$ 1.65-1.72 (m, 6H), $3.66(\mathrm{t}, 4 \mathrm{H}$, $J=4.86 \mathrm{~Hz}), 4.08(\mathrm{~s}, 3 \mathrm{H}), 6.54(\mathrm{~d}, 1 \mathrm{H}, J=3.0 \mathrm{~Hz}), 6.90(\mathrm{~d}, 1 \mathrm{H}$, $J=3.0 \mathrm{~Hz}), 7.19-7.25(\mathrm{~m}, 1 \mathrm{H}), 7.37-7.42(\mathrm{~m}, 1 \mathrm{H}), 7.78-7.92(\mathrm{~m}, 1 \mathrm{H})$, $8.14(\mathrm{~d}, 1 \mathrm{H}, J=8.2 \mathrm{~Hz}) ;{ }^{13} \mathrm{C}$ NMR $\left(\mathrm{CD}_{3} \mathrm{OD}, \mathrm{Me}_{4} \mathrm{Si}\right) \delta 25.1,26.2,38.2$, 49.7, 102.5, 113.9, 116.8, 119.9, 122.2, 126.2, 127.8, 131.1, 135.6, 150.6, 158.0; ESIMS $m / z 266.3(\mathrm{M}+\mathrm{H})^{+}$; HRMS calcd for $\mathrm{C}_{17} \mathrm{H}_{20} \mathrm{~N}_{3}$, 266.1657; found, 266.1642.

\subsubsection{1-Methyl-4-(4-methylpiperazin-1-yl)-1H-pyrrolo- [3,2-c]quinoline (9c)}

The crude product was purified by silica gel chromatography $\left(\mathrm{CH}_{2} \mathrm{Cl}_{2} / \mathrm{MeOH}=100: 1\right)$ to yield $20.73 \mathrm{mg}(80 \%)$ of the title compound.

${ }^{1} \mathrm{H} \mathrm{NMR}\left(\mathrm{CD}_{3} \mathrm{OD}, \mathrm{Me}_{4} \mathrm{Si}\right) \delta 2.31(\mathrm{~s}, 3 \mathrm{H}), 2.58(\mathrm{t}, 4 \mathrm{H}, J=4.9 \mathrm{~Hz}), 3.76$ $(\mathrm{t}, 4 \mathrm{H}, J=4.9 \mathrm{~Hz}), 4.12(\mathrm{~s}, 3 \mathrm{H}), 6.54(\mathrm{~d}, 1 \mathrm{H}, J=3.1 \mathrm{~Hz}), 6.89(\mathrm{~d}, 1 \mathrm{H}$, $J=3.1 \mathrm{~Hz}), 7.18-7.26(\mathrm{~m}, 1 \mathrm{H}), 7.37-7.43(\mathrm{~m}, 1 \mathrm{H}), 7.83(\mathrm{~d}, 1 \mathrm{H}$, $J=8.2 \mathrm{~Hz}), 8.14(\mathrm{~d}, 1 \mathrm{H}, J=8.2 \mathrm{~Hz}) ;{ }^{13} \mathrm{C}$ NMR $\left(\mathrm{CD}_{3} \mathrm{OD}, \mathrm{Me}_{4} \mathrm{Si}\right) \delta 38.2$, 46.2, 48.2, 55.2, 102.2, 113.5, 116.9, 120.0, 122.4, 126.3, 127.9, 128.1, 135.7, 144.4, 154.9; ESIMS $m / z 281.2(\mathrm{M}+\mathrm{H})^{+}$; HRMS calcd for $\mathrm{C}_{17} \mathrm{H}_{21} \mathrm{~N}_{4}, 281.1766$; found, 281.1777 .

\subsubsection{1-Methyl-4-morpholino-1H-pyrrolo-[3,2-c]quinoline (9d)}

The crude product was purified by silica gel chromatography $\left(\mathrm{CH}_{2} \mathrm{Cl}_{2} / \mathrm{MeOH}=100: 1\right)$ to yield $15.56 \mathrm{mg}$ (63\%) of the title compound.

${ }^{1} \mathrm{H}$ NMR $\left(\mathrm{CD}_{3} \mathrm{OD}, \mathrm{Me}_{4} \mathrm{Si}\right) \delta 3.70\left(\mathrm{t}, 4 \mathrm{H}, J=4.3 \mathrm{~Hz}, J^{\prime}=4.9 \mathrm{~Hz}\right), 3.86$ $\left(\mathrm{t}, 4 \mathrm{H}, J=4.3 \mathrm{~Hz}, J^{\prime}=4.9 \mathrm{~Hz}\right), 4.14(\mathrm{~s}, 3 \mathrm{H}), 6.51(\mathrm{~d}, 1 \mathrm{H}, J=3.1 \mathrm{~Hz}), 6.92$ $(\mathrm{d}, 1 \mathrm{H}, J=3.1 \mathrm{~Hz}), 7.26(\mathrm{t}, 1 \mathrm{H}, J=7.0 \mathrm{~Hz}), 7.42(\mathrm{t}, 1 \mathrm{H}, J=7 \mathrm{~Hz}), 7.85(\mathrm{~d}$, $1 \mathrm{H}, J=8.25 \mathrm{~Hz}), 8.17(\mathrm{~d}, 1 \mathrm{H}, J=8.25 \mathrm{~Hz}) ;{ }^{13} \mathrm{C} \mathrm{NMR}\left(\mathrm{CD}_{3} \mathrm{OD}, \mathrm{Me}_{4} \mathrm{Si}\right)$ $\delta$ 29.7, 38.2, 49.0, 67.1, 102.0, 113.5, 117.0, 120.0, 122.7, 126.4, 128.1, 135.3, 144.3, 154.9; ESIMS $m / z 268.1(\mathrm{M}+\mathrm{H})^{+}$; HRMS calcd for $\mathrm{C}_{16} \mathrm{H}_{18} \mathrm{~N}_{3} \mathrm{O}$, 268.1450; found, 268.1450 .

\subsubsection{N-Benzyl-1-methyl-1H-pyrrolo-[3,2-c]quinolin-4-amine (9e)}

The crude product was purified by silica gel chromatography $\left(\mathrm{CH}_{2} \mathrm{Cl}_{2} / \mathrm{MeOH}=100: 1\right)$ to yield $19.38 \mathrm{mg}$ (73\%) of the title compound.

${ }^{1} \mathrm{H}$ NMR $\left(\mathrm{CD}_{3} \mathrm{OD}, \mathrm{Me}_{4} \mathrm{Si}\right) \delta 4.14(\mathrm{~s}, 3 \mathrm{H}), 4.89(\mathrm{~d}, 2 \mathrm{H}, J=4.81 \mathrm{~Hz})$, $6.38(\mathrm{~d}, 1 \mathrm{H}, J=2.5 \mathrm{~Hz}), 6.88(\mathrm{~d}, 1 \mathrm{H}, J=2.9 \mathrm{~Hz}), 7.19-7.3(\mathrm{~m}, 5 \mathrm{H}), 7.39-$ $7.43(\mathrm{~m}, 2 \mathrm{H}), 7.84(\mathrm{~d}, 1 \mathrm{H}, J=8.2 \mathrm{~Hz}), 8.12(\mathrm{~d}, 1 \mathrm{H}, J=8.2 \mathrm{~Hz}) ;{ }^{13} \mathrm{C}$ NMR $\left(\mathrm{CD}_{3} \mathrm{OD}, \mathrm{Me}_{4} \mathrm{Si}\right) \delta 38.1,42.7,102.4,118.3,120.2,124.2,125.4,126.3$, $126.5,128.2,128.4,128.9,129.3,129.7,134.5,139.0,151.7$; ESIMS $m / z$ $288.0(\mathrm{M}+\mathrm{H})^{+}$; HRMS calcd for $\mathrm{C}_{19} \mathrm{H}_{18} \mathrm{~N}_{3}, 288.1501$; found, 288.1496.

\subsubsection{1-Methyl-4-(1H-pyrrol-1'-yl)-1H-pyrrolo-[3,2-c]-} quinoline (9f)

The crude product was purified by silica gel chromatography $\left(\mathrm{CH}_{2} \mathrm{Cl}_{2} / \mathrm{MeOH}=100: 1\right)$ to yield $19.88 \mathrm{mg}$ (87\%) of the title compound.

${ }^{1} \mathrm{H}$ NMR $\left(\mathrm{CD}_{3} \mathrm{OD}, \mathrm{Me}_{4} \mathrm{Si}\right) \delta 4.22(\mathrm{~s}, 3 \mathrm{H}), 6.34-6.38(\mathrm{~m}, 2 \mathrm{H}), 6.85$ $(\mathrm{d}, 1 \mathrm{H}, J=5.45 \mathrm{~Hz}), 7.06(\mathrm{~d}, 1 \mathrm{H}, J=5.45 \mathrm{~Hz}), 7.46(\mathrm{t}, 1 \mathrm{H}, J=6.94 \mathrm{~Hz})$, $7.57(\mathrm{t}, 1 \mathrm{H}, J=6.94 \mathrm{~Hz}), 7.64(\mathrm{~d}, 2 \mathrm{H}, J=6.3 \mathrm{~Hz}), 8.07(\mathrm{~d}, 1 \mathrm{H}, J=8.3 \mathrm{~Hz})$, 
$8.29(\mathrm{~d}, 1 \mathrm{H}, J=8.3 \mathrm{~Hz}) ;{ }^{13} \mathrm{C} \mathrm{NMR}\left(\mathrm{CD}_{3} \mathrm{OD}, \mathrm{Me}_{4} \mathrm{Si}\right) \delta 38.8,102.1,110.5$, 114.1, 118.1, 120.7, 124.9, 126.8, 128.8, 129.7, 129.9, 130.9, 136.8, 143.6; ESIMS $m / z 248.1(\mathrm{M}+\mathrm{H})^{+}$; HRMS calcd for $\mathrm{C}_{16} \mathrm{H}_{14} \mathrm{~N}_{3}$, 248.1188; found, 248.1182 .

\subsection{General procedure for the synthesis of 4-aryl-1-methyl- 1H-pyrrolo-[3,2-c]quinolines 10a-k}

To a mixture of imidoylchloride (20 $\mathrm{mg}, 9.25 \times 10^{-2} \mathrm{mmol}$ ), PEPPSI ( $1.25 \mathrm{mg}, 1.85 \mu \mathrm{mol}$ ), $\mathrm{Cs}_{2} \mathrm{CO}_{3}\left(45 \mathrm{mg}, 1.38 \times 10^{-1} \mathrm{mmol}\right.$ ), and boronic acid $\left(9.2510^{-2} \mathrm{mmol}\right)$ were added water $(1.5 \mathrm{ml})$ and dioxane $(1.5 \mathrm{ml})$, then the mixture was irradiated under microwaves for $2 \mathrm{~h}$ at $100{ }^{\circ} \mathrm{C}$. The mixture was diluted with $\mathrm{CH}_{2} \mathrm{Cl}_{2}(10 \mathrm{ml})$, washed with water $(2 \times 5 \mathrm{ml})$, dried over $\mathrm{MgSO}_{4}$, and concentrated under reduced pressure to obtain the title compounds.

\subsubsection{1-Methyl-4-phenyl-1H-pyrrolo-[3,2-c]quinoline (10a)}

Following the general procedure, the title compound was obtained in $84 \%$ yield as a white solid (20 mg).

${ }^{1} \mathrm{H} \mathrm{NMR}\left(\mathrm{CDCl}_{3}, \mathrm{Me}_{4} \mathrm{Si}\right) \delta 4.25(\mathrm{~s}, 3 \mathrm{H}), 6.78(\mathrm{~d}, 1 \mathrm{H}, J=3.1 \mathrm{~Hz}), 7.23$ $(\mathrm{d}, 1 \mathrm{H}, J=3.1 \mathrm{~Hz}), 7.40-7.61(\mathrm{~m}, 5 \mathrm{H}), 7.97(\mathrm{~d}, 2 \mathrm{H}, J=2.89 \mathrm{~Hz}), 8.24(\mathrm{~d}$, $1 \mathrm{H}, J=2.89 \mathrm{~Hz}), 8.34(\mathrm{~d}, 1 \mathrm{H}, J=2.89 \mathrm{~Hz}) ;{ }^{13} \mathrm{C} \mathrm{NMR}\left(\mathrm{CDCl}_{3}, \mathrm{Me}_{4} \mathrm{Si}\right)$ $\delta$ 38.2, 102.4, 118.3, 120.2, 120.4, 125.3, 126.3, 128.5, 128.6, 129.1, 129.7, 130.7, 134.8, 140.3, 144.7, 154.7; ESIMS $m / z 259.19(\mathrm{M}+\mathrm{H})^{+}$; HRMS calcd for $\mathrm{C}_{18} \mathrm{H}_{15} \mathrm{~N}_{2}$, 259.1235; found, 259.12138.

\subsubsection{1-Methyl-4-o-tolyl-1H-pyrrolo-[3,2-c]quinoline (10b)}

Following the general procedure, the title compound was obtained in $70 \%$ yield as a white solid $(17.6 \mathrm{mg})$.

${ }^{1} \mathrm{H} \mathrm{NMR}\left(\mathrm{CDCl}_{3}, \mathrm{Me}_{4} \mathrm{Si}\right) \delta 2.21(\mathrm{~s}, 3 \mathrm{H}), 4.26(\mathrm{~s}, 3 \mathrm{H}), 6.34(\mathrm{~d}, 1 \mathrm{H}$, $J=3.0 \mathrm{~Hz}), 7.00(\mathrm{~d}, 1 \mathrm{H}, J=3.0 \mathrm{~Hz}), 7.48-7.60(\mathrm{~m}, 6 \mathrm{H}), 8.22(\mathrm{~d}, 1 \mathrm{H}$, $J=8.3 \mathrm{~Hz}), 8.38(\mathrm{~d}, 1 \mathrm{H}, J=8.3 \mathrm{~Hz}) ;{ }^{13} \mathrm{C}$ NMR $\left(300 \mathrm{MHz}, \mathrm{CDCl}_{3}\right) \delta 20.0$, 38.0, 103.1, 118.4, 120.2, 121.7, 124.7, 125.5, 126.2, 128.2, 129.4, 129.6, 130.6, 130.6, 134.2, 136.4, 139.5, 144.5, 156.3; ESIMS $m / z 273.1$ $(\mathrm{M}+\mathrm{H})^{+}$; HRMS calcd for $\mathrm{C}_{19} \mathrm{H}_{17} \mathrm{~N}_{2}, 273.1392$; found, 273.1387.

\subsubsection{1-Methyl-4-m-tolyl-1H-pyrrolo-[3,2-c]quinoline (10c)}

Following the general procedure, the title compound was obtained in $74 \%$ yield as a white solid $(18.7 \mathrm{mg}$ ).

${ }^{1} \mathrm{H}$ NMR $\left(\mathrm{CDCl}_{3}, \mathrm{Me}_{4} \mathrm{Si}\right) \delta 2.65(\mathrm{~s}, 3 \mathrm{H}), 4.52(\mathrm{~s}, 3 \mathrm{H}), 7.05(\mathrm{~d}, 1 \mathrm{H}$, $J=3.1 \mathrm{~Hz}), 7.31(\mathrm{~d}, 1 \mathrm{H}, J=3.1 \mathrm{~Hz}), 7.55(\mathrm{~d}, 2 \mathrm{H}, J=7.9 \mathrm{~Hz}), 7.72-7.85(\mathrm{~m}$, $2 \mathrm{H}), 8.14(\mathrm{~d}, 2 \mathrm{H}, J=7.9 \mathrm{~Hz}), 8.49(\mathrm{~d}, 1 \mathrm{H}, J=8.3 \mathrm{~Hz}), 8.61(\mathrm{~d}, 1 \mathrm{H}$, $J=8.3 \mathrm{~Hz}) ;{ }^{13} \mathrm{C} \mathrm{NMR}\left(\mathrm{CDCl}_{3}, \mathrm{Me}_{4} \mathrm{Si}\right) \delta 21.4,38.1,103.2,118.1,120.2$, 121.8, 125.0, 125.7, 126.2, 128.4, 129.2, 129.5, 130.6, 130.7, 134.3, 136.4, 139.5, 144.5, 156.3; ESIMS $m / z 273.1(\mathrm{M}+\mathrm{H})^{+}$; HRMS calcd for $\mathrm{C}_{19} \mathrm{H}_{17} \mathrm{~N}_{2}, 273.1392$; found, 273.1387.

\subsubsection{1-Methyl-4-p-tolyl-1H-pyrrolo-[3,2-c]quinoline (10d)}

Following the general procedure, the title compound was obtained in $73 \%$ yield as a white solid ( $18.4 \mathrm{mg}$ ).

${ }^{1} \mathrm{H} \mathrm{NMR}\left(\mathrm{CDCl}_{3}, \mathrm{Me}_{4} \mathrm{Si}\right) \delta 2.48(\mathrm{~s}, 3 \mathrm{H}), 4.31(\mathrm{~s}, 3 \mathrm{H}), 6.87(\mathrm{~s}, 1 \mathrm{H})$, $7.12(\mathrm{~s}, 1 \mathrm{H}), 7.38$ (d, 2H, J=9 Hz), 7.57-7.65 (m, 2H), 7.98 (d, 2H,

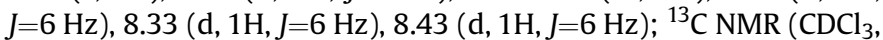
$\left.\mathrm{Me}_{4} \mathrm{Si}\right) \delta$ 21.4, 38.1, 103.1, 118.3, 120.4, 125.2, 126.9, 127.7, 129.0, 129.2, 129.6, 130.6, 134.8, 137.5, 138.7, 144.7, 154.8; ESIMS $m / z$ $273.0(\mathrm{M}+\mathrm{H})^{+}$; HRMS calcd for $\mathrm{C}_{19} \mathrm{H}_{17} \mathrm{~N}_{2}, 273.1392$; found, 273.1391.

\subsubsection{4-(2'-Methoxyphenyl)-1-methyl-1H-pyrrolo-[3,2-c]- quinoline (10e)}

Following the general procedure, the title compound was obtained in $75 \%$ yield as a white solid $(20 \mathrm{mg})$.

${ }^{1} \mathrm{H}$ NMR (300 MHz, CDCl $) \delta 3.83(\mathrm{~s}, 3 \mathrm{H}), 4.25(\mathrm{~s}, 3 \mathrm{H}), 6.67(\mathrm{~d}, 1 \mathrm{H}$, $J=3.1 \mathrm{~Hz}), 6.96-7.05(\mathrm{~m}, 3 \mathrm{H}), 7.44-7.58(\mathrm{~m}, 2 \mathrm{H}), 7.95(\mathrm{~d}, 2 \mathrm{H}$, $J=8.8 \mathrm{~Hz}), 8.22(\mathrm{~d}, 1 \mathrm{H}, J=8.0 \mathrm{~Hz}), 8.34(\mathrm{~d}, 1 \mathrm{H}, J=8.0 \mathrm{~Hz}) ;{ }^{13} \mathrm{C} \mathrm{NMR}$ $\left(\mathrm{CDCl}_{3}, \mathrm{Me}_{4} \mathrm{Si}\right) \delta 38.1,55.4,103.1,113.9,114.5,118.2,120.1,120.3$,
125.1, 126.3, 128.2, 129.6, 130.4, 130.5, 133.0, 135.0, 144.7, 154.3, 160.2; ESIMS $m / z 289.1(\mathrm{M}+\mathrm{H})^{+}$; HRMS calcd for $\mathrm{C}_{19} \mathrm{H}_{17} \mathrm{~N}_{2} \mathrm{O}$, 289.1341 ; found, 289.1342 .

\subsubsection{4-(4'-Fluorophenyl)-1-methyl-1H-pyrrolo-[3,2-c]-}

quinoline (10f)

Following the general procedure, the title compound was obtained in $90 \%$ yield as a white solid $(23 \mathrm{mg})$.

${ }^{1} \mathrm{H} \mathrm{NMR}\left(\mathrm{CDCl}_{3}, \mathrm{Me}_{4} \mathrm{Si}\right) \delta 4.26(\mathrm{~s}, 3 \mathrm{H}), 6.73(\mathrm{~d}, 1 \mathrm{H}, \mathrm{J}=3.1 \mathrm{~Hz}), 7.05$ $(\mathrm{d}, 1 \mathrm{H}, J=3.1 \mathrm{~Hz}), 7.12-7.19(\mathrm{~m}, 2 \mathrm{H}), 7.47-7.60(\mathrm{~m}, 2 \mathrm{H}), 7.93-7.99(\mathrm{~m}$, $2 \mathrm{H}), 8.2(\mathrm{~d}, 1 \mathrm{H}, J=7.7 \mathrm{~Hz}), 8.39(\mathrm{~d}, 1 \mathrm{H}, J=7.7 \mathrm{~Hz}) ;{ }^{13} \mathrm{C}$ NMR (acetone, $\left.\mathrm{Me}_{4} \mathrm{Si}\right) \delta 38.3,102.3,115.8,116.1,120.7,121.7,126.2,127.0,131.2$, 131.5, 131.87, 131.97, 135.7, 137.8, 145.4, 153.3, 162.45, 165.7; ESIMS $m / z 277.1(\mathrm{M}+\mathrm{H})^{+}$; HRMS calcd for $\mathrm{C}_{18} \mathrm{H}_{14} \mathrm{~N}_{2} \mathrm{~F}, 277.1141$; found, 277.1136 .

\subsubsection{1-Methyl-4-(4'-(trifluoromethoxy)phenyl)-1H-pyrrolo- [3,2-c]quinoline (10g)}

Following the general procedure, the title compound was obtained in $76 \%$ yield as a white solid $(24.05 \mathrm{mg})$.

${ }^{1} \mathrm{H} \mathrm{NMR}\left(\mathrm{CDCl}_{3}, \mathrm{Me}_{4} \mathrm{Si}\right) \delta 4.24(\mathrm{~s}, 3 \mathrm{H}), 6.73(\mathrm{~d}, 1 \mathrm{H}, J=3.1 \mathrm{~Hz}), 7.06$ (d, $1 \mathrm{H}, J=3.1 \mathrm{~Hz}$ ), 7.28-7.33 (m, 2H), 7.48-7.60 (m, 2H), 7.98-8.03 $(\mathrm{m}, 2 \mathrm{H}), 8.22(\mathrm{~d}, 1 \mathrm{H}, J=7.8 \mathrm{~Hz}), 8.36(\mathrm{~d}, 1 \mathrm{H}, J=7.8 \mathrm{~Hz}) ;{ }^{13} \mathrm{C}$ NMR $\left(\mathrm{CDCl}_{3}, \mathrm{Me}_{4} \mathrm{Si}\right) \delta 38.2,102.7,118.3,120.17,120.2,121.0,122.2,125.6$, 126.5, 129.93, 130.6, 130.7, 135.0, 139.0, 144.6, 149.7, 153.2; ESIMS m/ $z 342.9(\mathrm{M}+\mathrm{H})^{+}$; HRMS calcd for $\mathrm{C}_{19} \mathrm{H}_{14} \mathrm{~N}_{2} \mathrm{OF}_{3}, 343.1058$; found, 343.1082 .

\subsubsection{1-Methyl-4-(naphthalen-1'-yl)-1H-pyrrolo-[3,2-c]- quinoline (10h)}

Following the general procedure, the title compound was obtained in $84 \%$ yield as a white solid $(23.9 \mathrm{mg})$.

${ }^{1} \mathrm{H} \mathrm{NMR}\left(\mathrm{CDCl}_{3}, \mathrm{Me}_{4} \mathrm{Si}\right) \delta 4.27(\mathrm{~s}, 3 \mathrm{H}), 6.27(\mathrm{~d}, 1 \mathrm{H}, J=3 \mathrm{~Hz}), 6.97$ (d, $1 \mathrm{H}, J=3 \mathrm{~Hz}$ ), $7.33-7.68$ (m, 5H), 7.69 (d, 1H, $J=6.8 \mathrm{~Hz}), 7.81$ (m,

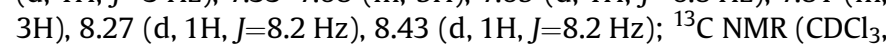
$\left.\mathrm{Me}_{4} \mathrm{Si}\right) \delta$ 38.1, 103.3, 118.5, 120.3, 122.5, 125.3, 125.6, 126.0, 126.4 127.9, 128.1, 129.6, 130.8, 131.8, 132.8, 133.5, 134.0, 134.4, 137.5, 138.4, 144.6, 155.2; ESIMS $\mathrm{m} / \mathrm{z} 309.1(\mathrm{M}+\mathrm{H})^{+}$; HRMS calcd for $\mathrm{C}_{22} \mathrm{H}_{17} \mathrm{~N}_{2}$, 309.1392; found, 309.1387.

\subsubsection{4-Biphenyl-1-methyl-1H-pyrrolo-[3,2-c]quinoline (10i)}

Following the general procedure, the title compound was obtained in $80 \%$ yield as a white solid $(20 \mathrm{mg})$.

${ }^{1} \mathrm{H} \mathrm{NMR}\left(\mathrm{CDCl}_{3}, \mathrm{Me}_{4} \mathrm{Si}\right) \delta 4.25(\mathrm{~s}, 3 \mathrm{H}), 6.83(\mathrm{~d}, 1 \mathrm{H}, J=3.1 \mathrm{~Hz}), 7.23$ $(\mathrm{d}, 1 \mathrm{H}, J=3.1 \mathrm{~Hz}), 7.28-7.66(\mathrm{~m}, 7 \mathrm{H}), 7.71(\mathrm{~d}, 2 \mathrm{H}, J=8.4 \mathrm{~Hz}), 8.07(\mathrm{~d}$ $2 \mathrm{H}, J=8.4 \mathrm{~Hz}), 8.24(\mathrm{~d}, 1 \mathrm{H}, J=8.3 \mathrm{~Hz}), 8.37(\mathrm{~d}, 1 \mathrm{H}, J=8.3 \mathrm{~Hz}) ;{ }^{13} \mathrm{C} \mathrm{NMR}$ $\left(\mathrm{CDCl}_{3}, \mathrm{Me}_{4} \mathrm{Si}\right) \delta 38.2,103.1,118.3,120.2,120.4,125.4,126.4,127.1$, 127.2, 127.3, 127.4, 127.6, 127.8, 128.82, 128.89, 129.6, 129.7, 130.7, 134.9, 139.3, 140.9, 141.6, 144.8, 154.3; ESIMS $m / z 335.1(\mathrm{M}+\mathrm{H})^{+}$; HRMS calcd for $\mathrm{C}_{24} \mathrm{H}_{19} \mathrm{~N}_{2}$, 335.54; found, 335.1548 .

\subsubsection{4-(Benzofuran-2'-yl)-1-methyl-1H-pyrrolo-[3,2-c]- quinoline (10j)}

Following the general procedure, the title compound was obtained in $91 \%$ yield as a white solid $(25 \mathrm{mg})$.

${ }^{1} \mathrm{H} \mathrm{NMR}\left(\mathrm{CDCl}_{3}, \mathrm{Me}_{4} \mathrm{Si}\right) \delta 4.22(\mathrm{~s}, 3 \mathrm{H}), 7.09(\mathrm{t}, 1 \mathrm{H}, \mathrm{J}=3.0 \mathrm{~Hz}), 7.18-$ $7.33(\mathrm{~m}, 3 \mathrm{H}), 7.45-7.66(\mathrm{~m}, 5 \mathrm{H}), 8.24$ (d, $1 \mathrm{H}, J=8.1 \mathrm{~Hz}), 8.32(\mathrm{~d}, 1 \mathrm{H}$ $J=8.1 \mathrm{~Hz}) ;{ }^{13} \mathrm{C} \mathrm{NMR}\left(\mathrm{CDCl}_{3}, \mathrm{Me}_{4} \mathrm{Si}\right) \delta 38.2,103.2,107.3,111.8,118.6$, 119.1,120.2, 121.7, 123.1, 125.2, 125.7, 126.5, 128.6, 130.2, 130.7, 135.3, 144.09, 144.5, 155.5, 156.1; ESIMS $m / z 299.0(\mathrm{M}+\mathrm{H})^{+}$; HRMS calcd for $\mathrm{C}_{20} \mathrm{H}_{15} \mathrm{~N}_{2} \mathrm{O}$, 299.1184; found, 299.1197.

\subsubsection{1-Methyl-4-(1',2',3', $4^{\prime}$-tetrahydro-1', $1^{\prime}, 4^{\prime}, 4^{\prime}$-tetramethyl-} naphthalen-6-yl)-1H-pyrrolo-[3,2-c]quinoline (10k)

Following the general procedure, the title compound was obtained in $73 \%$ yield as a white solid $(24.7 \mathrm{mg})$. 
${ }^{1} \mathrm{H} \mathrm{NMR}\left(\mathrm{CDCl}_{3}, \mathrm{Me}_{4} \mathrm{Si}\right) \delta 1.21-1.31(\mathrm{~m}, 12 \mathrm{H}), 1.54-1.68(\mathrm{~m}, 4 \mathrm{H})$, $4.26(\mathrm{~s}, 3 \mathrm{H}), 6.77(\mathrm{~d}, 1 \mathrm{H}, J=3 \mathrm{~Hz}), 7.04(\mathrm{~d}, 1 \mathrm{H}, J=3 \mathrm{~Hz}), 7.40-7.56(\mathrm{~m}$, $3 \mathrm{H}), 7.73(\mathrm{~d}, 1 \mathrm{H}, J=9.0 \mathrm{~Hz}), 7.88(\mathrm{~s}, 1 \mathrm{H}), 8.23(\mathrm{~d}, 1 \mathrm{H}, J=3.0 \mathrm{~Hz}), 8.34$ $(\mathrm{d}, 1 \mathrm{H}, J=3.0 \mathrm{~Hz}) ;{ }^{13} \mathrm{C} \mathrm{NMR}\left(\mathrm{CDCl}_{3}, \mathrm{Me}_{4} \mathrm{Si}\right) \delta 31.8,31.9,34.3,34.4$, $35.1,35.2,38.1,103.3,112.7,118.3,120.1,124.5,125.1,126.2,127.0$, $127.51,129.5,130.7,134.8,137.4,138.9,144.6,144.8,145.0,145.6$, 155.2; ESIMS $m / z 369.0(\mathrm{M}+\mathrm{H})^{+}$; HRMS calcd for $\mathrm{C}_{26} \mathrm{H}_{29} \mathrm{~N}_{2}$, 369.2331; found, 369.2333 .

\section{Acknowledgements}

We thank the MENRT, the CNRS, and la Ligue contre le Cancer for financial support.

\section{References and notes}

2. Microwave in Organic Synthesis, 2nd ed.; Loupy, A., Ed.; Wiley-VCH: Weinheim, 2006.

3. Mont, N.; Fernandez-Megido, L.; Teixido, J.; Kappe, C. O.; Borrell, J. I. QSAR Comb Sci. 2004, 23, 836-849.

4. Stadler, A.; Kappe, C. O. Tetrahedron 2001, 57, 3915-3920.

5. Helissey, P.; Parrot-Lopez, H.; Renault, J.; Cros, S. Eur. J. Med. Chem. 1987, 22, 366-368.

6. Wright, G. C.; Watson, E. J.; Ebetino, F. F.; Lougheed, G.; Stevenson, B. F.; Winterstein, A.; Bickerton, R. K.; Halliday, R. P.; Pals, D. T. J. Med. Chem. 1971, 14 1060-1066.

7. Leach, C. A.; Brown, T. H.; Ife, R. J.; Keeling, D. J.; Laing, S. M.; Parsons, M. E.; Price, C. A.; Wiggall, K. J. J. Med. Chem. 1992, 35, 1845-1852.

8. Escolano, C.; Jones, K. Tetrahedron Lett. 2000, 41, 8951-8955.

9. Brown, T. H.; Ife, R. J.; Keeling, D. J.; Laing, S. M.; Leach, C. A.; Parsons, M. E.; Price, C. A.; Reavill, D. R.; Wiggall, K. J. J. Med. Chem. 1990, 33, 527-533.

10. Testa, M. L.; Lamartina, L.; Mingoia, F. Tetrahedron 2004, 60, 5873-5880.

11. Campiani, G.; Cappelli, A.; Nacci, V.; Anzini, M.; Vomero, S.; Hamon, M.; Cagnotto, A.; Fracasso, C.; Uboldi, C.; Caccia, S.; Consolo, S.; Mennini, T. J. Med. Chem. 1997, 40, 3670-3678.

12. Campiani, G.; Morelli, E.; Gemma, S.; Nacci, V.; Butini, S.; Hamon, M.; Novellino, E.; Greco, G.; Cagnotto, A.; Goegan, M.; Cervo, L.; Dalla Valle, F.; Fracasso, C.; Caccia, S.; Mennini, T. J. Med. Chem. 1999, 42, 4362-4379.

13. Cappelli, A.; Anzini, M.; Vomero, S.; Canullo, L.; Mennuni, L.; Makovec, F.; Doucet, E.; Hamon, M.; Menziani, M. C.; De Benedetti, P. G.; Bruni, G.; Romeo, M. R.; Giorgi, G.; Donati, A. J. Med. Chem. 1999, 42, 1556-1575.

14. Keith, M. W.; Richard, W. R.; Amy, C. G.; Aurora, M. B.; Michael, J. S.; William, C. L.; Steven, M. P.; Sandor, L. V. J. Am. Chem. Soc. 1995, 117, 6682-6685.

15. Kang, S. K.; Park, S. S.; Kim, S. S.; Choi, J.-K.; Yum, E. K. Tetrahedron Lett. 1999, 40 4379-4382.

16. Lovely, C. J.; Mahmud, H. Tetrahedron Lett. 1999, 40, 2079-2082.
17. Declerck, V.; Allouchi, H.; Martinez, J.; Lamaty, F. J. Org. Chem. 2007, 72, 1518-1521.

18. Declerck, V.; Ribiere, P.; Martinez, J.; Lamaty, F. J. Org. Chem. 2004, 69, 8372-8381.

19. Peng, Z.-H.; Journet, M.; Humphrey, G. Org. Lett. 2006, 8, 395-398.

20. Rouden, J.; Bernard, A.; Lasne, M.-C. Tetrahedron Lett. 1999, 40, 8109-8112.

21. Wagaw, S.; Buchwald, S. L. J. Org. Chem. 1996, 61, 7240-7241.

22. wolfe, J. P.; Buchwald, S. L. Angew. Chem., Int. Ed. 1999, 38, 2413-2416.

23. Dawood, K. M. Tetrahedron 2007, 63, 9642-9651.

24. Koubachi, J.; El Kazzouli, S.; Berteina-Raboin, S.; Mouaddib, A.; Guillaumet, G. J. Org. Chem. 2007, 72, 7650-7655.

25. Nadin, A.; Sanchez Lopez, J. M.; Owens, A. P.; Howells, D. M.; Talbot, A. C.; Harrison, T. J. Org. Chem. 2003, 68, 2844-2852.

26. Shieh, W. C.; Carlson, J. A. J. Org. Chem. 1992, 57, 379-381.

27. Song-Se, Y.; Lee, D.-H.; Sin, E.; Lee, Y.-S. Tetrahedron Lett. 2007, 48, 6771-6775.

28. Donohoe, T. J.; Orr, A. J.; Bingham, M. Angew. Chem., Int. Ed. 2006, 45, 2664-2670.

29. Dieltiens, N.; Stevens, C. V.; De Vos, D.; Allaert, B.; Drozdzak, R.; Verpoort, F. Tetrahedron Lett. 2004, 45, 8995-8998.

30. Dieltiens, N.; Stevens, C. V.; Allaert, B.; Verpoort, F. ARKIVOC 2005, 92-97.

31. Balan, D.; Adolfsson, H. J. Org. Chem. 2001, 66, 6498-6501.

32. Balan, D.; Adolfsson, H. J. Org. Chem. 2002, 67, 2329-2334.

33. Balan, D.; Adolfsson, H. Tetrahedron Lett. 2003, 44, 2521-2524.

34. Bertenshaw, S.; Kahn, M. Tetrahedron Lett. 1989, 30, 2731-2732.

35. Kwong, C. K.-W.; Huang, R.; Zhang, M.; Shi, M.; Toy, P. H. Chem.-Eur. J. 2007, 13, 2369-2376.

36. Lee, K. Y.; Kim, J. M.; Kim, J. N. Tetrahedron 2003, 59, 385-390.

37. Ribiere, P.; Enjalbal, C.; Aubagnac, J.-L.; Yadav-Bhatnagar, N.; Martinez, J.; Lamaty, F. J. Comb. Chem. 2004, 6, 464-467.

38. Ribiere, P.; Yadav-Bhatnagar, N.; Martinez, J.; Lamaty, F. QSAR Comb. Sci. 2004 23, 911-914.

39. Richter, H.; Jung, G. Tetrahedron Lett. 1998, 39, 2729-2730.

40. Shi, Y.-L.; Shi, M. Eur. J. Org. Chem. 2007, 2007, 2905-2916.

41. Vasudevan, A.; Tseng, P.-S.; Djuric, S. W. Tetrahedron Lett. 2006, 47, 5891-5893.

42. Tao, Y. T.; Chen, M. L. J. Org. Chem. 1988, 53, 69-72.

43. Handbook of Metathesis, Grubbs, R. H., Ed.; Wiley-VCH: Weinheim, 2003.

44. Bieniek, M.; Bujok, R.; Cabaj, M.; Lugan, N.; Lavigne, G.; Arlt, D.; Grela, K. J. Am. Chem. Soc. 2006, 128, 13652-13653.

45. Michrowska, A.; Bujok, R.; Harutyunyan, S.; Sashuk, V.; Dolgonos, G.; Grela, K. J. Am. Chem. Soc. 2004, 126, 9318-9325.

46. Ono, K.; Nagata, T.; Nishida, A. Synlett 2003, 1207-1209.

47. Kundu, N. G.; Nandi, B. J. Org. Chem. 2001, 66, 4563-4575.

48. Nandi, B.; Kundu, N. G. Org. Lett. 2000, 2, 235-238.

49. Guenoun, F.; Lazaro, R.; Negro, A.; Viallefont, P. Tetrahedron Lett. 1990, 31, 2153-2156.

50. Helissey, P.; Parrot-Lopez, H.; Renault, J.; Cros, S. Chem. Pharm. Bull. 1987, 35 , 3547-3557.

51. Organ, M. G.; Avola, S.; Dubovyk, I.; Hadei, N.; Kantchev, E. A. B.; O’Brien, C. J.; Valente, C. Chem.-Eur. J. 2006, 4749-4755.

52. Culkin, D. A.; Hartwig, J. F. Organometallics 2004, 23, 3398-3416.

53. Mann, G.; Shelby, Q.; Roy, A. H.; Hartwig, J. F. Organometallics 2003, 22, 2775-2789. 